\title{
Major thoracic vessels and cardiac trauma: case series from a center in a developing country
}

\author{
Majör toraks damarları ve kardiyak travma: \\ Gelişmekte olan ülkeden olgu serisi
}

\author{
Saulat H. FATIMI, ${ }^{1}$ Hashim M. HANIF, ${ }^{2}$ Anum AWAIS, ${ }^{2}$ Ghina SHAMSI, ${ }^{1}$ Marium MUZAFFAR ${ }^{2}$
}

\section{BACKGROUND}

Seventy-five percent of all trauma-related deaths are related to thoracic trauma. Very few penetrating cardiac trauma patients arrive to the hospital alive. Due to its high prevalence, an understanding of the pathogenesis, manifestations and management of cardiac trauma by the medical personnel is becoming increasingly important.

\section{METHODS}

We retrospectively reviewed the files of 169 patients with a preoperative diagnosis of vascular injury who underwent management at the Aga Khan University Hospital from 2001 to 2006. Of these patients, 13 had cardiovascular and cardiac injuries.

\section{RESULTS}

$23 \%(n=3)$ had cardiac injuries; 2 had right ventricle injuries and 1 had injury to both ventricles. Great vessel injuries included: pulmonary artery $(\mathrm{n}=2)$, inferior vena cava $(n=1)$, left carotid artery $(n=1)$, left subclavian artery $(n=2)$, and right subclavian artery $(\mathrm{n}=3) .53 .8 \%$ of the patients suffered from postoperative complications. The overall mortality of patients with major thoracic vessel and cardiac trauma was found to be $15.4 \%$.

\section{CONCLUSION}

We believe that, in the past, the inevitable delay in diagnosis led to unsuccessful thoracotomies, late transfers to the operating room and physiological deterioration of the patient. As the incidence of trauma is increasing worldwide, it is essential for surgeons to be prepared to handle cardiovascular and cardiac trauma injuries immediately, as delay can adversely affect the outcome in terms of both morbidity and mortality. All patients presenting with trauma to the chest should be assessed with a high index of suspicion for major cardiovascular injuries. Early diagnosis, prompt transfer to the operating room and speedy and perfect surgery influence a favorable outcome.

Key Words: Cardiac trauma; major thoracic vessel trauma.

\section{$A M A C ̧$}

Travmayla ilişkili ölümlerin \%75'i gögüs travmasını ilgilendirir. Çok az sayıda penetran kardiyak travma hastası hastaneye yaşarken ulaşmaktadır. Yüksek prevalansı nedeniyle tıp mensupları için kardiyak travmanın patogenezi, belirtileri ve tedavisinin anlaşılması giderek daha fazla önem taşımaktadır.

\section{GEREÇ VE YÖNTEM}

Ameliyat öncesi damar yaralanması tanısı konmuş ve 20012006 yılları arasında Aga Han Üniversite Hastanesi'nde tedavi edilmiş 169 hastanın dosyasını geriye dönük olarak gözden geçirdik. Bu hastaların 13'ü kardiyovasküler ve kardiyak travmalar geçirmişti.

\section{BULGULAR}

İki sağ ventrikül ve bir her iki ventrikül yaralanması olmak üzere $3(\% 23)$ kalp travması vardı. Büyük damarlarda etkilenmişti: Pulmoner arter $(n=2)$, inferior vena kava $(n=1)$, sol karotis arter $(n=1)$, sol subklavyen arter $(n=2)$ ve sağ subklavyen arter $(\mathrm{n}=3)$. Hastaların $\% 53,8^{\prime} \mathrm{i}$ ameliyat sonrası komplikasyonlar geçirmişti. Majör toraks damarları ve kardiyak travmalı hastalarda genel mortalite oranı $\% 15,4$ bulundu.

\section{SONUÇ}

Bu retrospektif değerlendirmeye göre tanıda kaçınılmaz gecikme başarısız torakotomilere, ameliyathaneye geç sevklere ve hastaların kötüleşmesine yol açtığına inanmaktayız. Dünya ölçeğinde travmaların görülme sıklığı arttığına göre, gecikme hem morbidite hem de mortalite sonuçlarını olumsuz etkileyebildiğimnden cerrahların kardiyovasküler ve kardiyak travmalara acilen müdahale etmeye hazırlıklı olmaları gerekir. Göğüs travması ile başvuran tüm hastalar majör kardiyovasküler yaralanma yüksek şüphe indeksi ile değerlendirilmelidir. Erken tanı, ameliyathaneye hızlı nakil, hızlı ve kusursuz cerrahi girişim yüz güldürücüdür.

Anahtar Sözcükler: Kardiyak travma; majör toraks damarı yaralanmas1.
${ }^{1}$ Department of Surgery, Division of Cardiothoracic Surgery,
Aga Khan University, Karachi;

${ }^{2}$ Medical College, Aga Khan University, Karachi, Pakistan.
${ }^{1}$ Aga Khan Üniversitesi Tıp Fakültesi, Kalp Cerrahisi Anabilim Dalı,
Karachi;

${ }^{2}$ Aga Khan Üniversitesi, Tıp Koleji, Karachi, Pakistan.

Correspondence (İletişim): Hashim M Hanif, M.D. Department of Cardiothoracic Surgery, Aga Khan University, Stadium Road, 74800 Karachi, Pakistan. Tel: +92 - 321 - 2101375 e-mail (e-posta): hashimhanif@gmail.com 
Seventy-five percent of all trauma-related deaths are related to thoracic trauma. ${ }^{[1]}$ Ten to fifteen percent of patients require definitive operative repair. ${ }^{[2,3]}$ Of the two subsets of thoracic trauma, blunt and penetrating, very few penetrating cardiac trauma patients arrive to the hospital alive, ${ }^{[4]}$ Thus, rapid diagnosis and operative treatment are imperative to salvage lives that would otherwise be lost. ${ }^{[5]}$

Cardiothoracic injury causes $25 \%$ of deaths immediately following trauma, and the majority of these fatalities involve either cardiac or great vessel injury. ${ }^{[6]}$ In addition, between 25,000 and 30,000 Americans die from gunshot wounds each year, and $10 \%$ of these deaths are the direct result of penetrating cardiac trauma. ${ }^{[7]}$ Due to the high prevalence of this type of injury, an understanding of the pathogenesis, manifestations and management of cardiac trauma by the medical personnel is becoming increasingly important.

Cardiac injury may involve the myocardium, coronary arteries, valves, or septum or presentation of a ventricular aneurysm, and mortality ranges from 10$70 \% .{ }^{[8]}$ Trauma patients who do suffer inferior vena cava (IVC) injuries have an exceedingly high mortality rate of $43 \% .{ }^{[9]}$ Penetrating wounds cause approximately $90 \%$ of injuries to branches of the arch. The innominate and subclavian vessels are the most commonly injured. ${ }^{[10]}$

Despite the uncommon occurrence, such injuries require a high index of suspicion, and prompt recognition and correct approach are required to change the outcome. The mortality rate in patients with blunt chest trauma and penetrating cardiac wounds has been reported to be as high as $60 \% .^{[11,12]}$

We present a case series of 13 patients with major thoracic vessels and cardiac trauma who presented to us over the period 2001-2006. The purpose of the study was to review the algorithm of their management and the outcomes in terms of morbidity and mortality.

\section{MATERIALS AND METHODS}

We retrospectively reviewed the files of 169 patients with a preoperative diagnosis of vascular injury who underwent management at the Aga Khan University Hospital during the period 2001-2006.

Of the 169 patients, the records of 22 were missing; the remaining 147 patients were stratified into three groups according to their management algorithm. These groups were designated as observation $(n=57)$, minimal intervention $(n=67)$ and major thoracic trauma $(n=28)$. In the subset of our interest, major thoracic trauma, 15 patients had tracheobronchial injury and 13 had cardiovascular and cardiac injuries.

We defined major cardiac and vascular trauma of the thoracic cavity as being highly fatal if untreated and requiring immediate intervention. Age, sex, time between injury and presentation, diagnostic modality used, time between presentation and beginning of surgery, surgical interventions performed, other associated injuries, and outcome are reported based on the retrospective audit. In this study, we included all patients with cardiac and/or cardiovascular injuries, and there was no criterion for exclusion.

In our cases of cardiac and cardiovascular trauma $(n=13)$, demographics, types of injuries, associated or concomitant trauma, status at presentation, modes of presentation, time lag between injury and arrival to the hospital and start of the surgery, operative procedures, and patient outcomes in terms of morbidity and mortality were noted.

Cardiovascular trauma is caused by various mechanisms. Deceleration and traction are the classic wounding mechanisms of the thoracic arteries. Horizontal deceleration creates shearing forces at the aortic isthmus, the junction between the aortic arch and the descending aorta. ${ }^{[13,14]}$ Cardiac trauma can be secondary to massive compression of the chest that may crush the heart and ascending aorta. Direct injury to the right ventricle can be caused by a fractured rib. ${ }^{[15-}$ ${ }^{18]}$ In this study, we classified types of injury according to the site and mode (blunt or penetrating). Concomitant injuries were also noted.

Diagnosis of the cases was done according to physical examination, chest radiography, computed tomography (CT), ultrasound, echocardiography, and angiography. The patient's hemodynamic status at presentation was also studied. The management algorithm entailed early diagnosis, resuscitation (Advanced Basic Life Support), emergent thoracotomy in the emergency room, and definitive surgery by the trauma team in the operating room (OR).

\section{RESULTS}

A total of 13 patients with cardiac and cardiovascular injuries were treated during the five-year study period. The mean age was 26 years (range, 13-49). The majority of the patients were males $(84.6 \%, 11$ of 13$)$. (Table 1) Penetrating injuries were present in $72 \%$, blunt injuries in $21 \%$, and combined injuries in $7 \%$.

Cardiac injuries were present in $23 \%(n=3)$; two

Table 1. Demographics

\begin{tabular}{lc}
\hline Age (range) & $13-49$ \\
Mean age & 26 \\
Gender & \\
$\quad$ Male & 11 \\
Female & 2 \\
\hline
\end{tabular}


Table 2. Types of injuries

\begin{tabular}{llll}
\hline Types of injuries (site) & $\mathrm{n}$ & Associated injuries (concomitant) & $\mathrm{n}$ \\
\hline Right pulmonary artery & 2 & Airway injury & 1 \\
Injury to both ventricles/ (VSD) & 1 & Major abdominal injury & 3 \\
Right ventricle injury & 2 & Head injury & 1 \\
Inferior vena cava & 1 & Orthopedic injuries & \\
Left carotid artery & 1 & & \\
Left subclavian artery & 2 & & \\
Right subclavian artery & 3 & & \\
Left internal mammary artery & 1 & & \\
\hline
\end{tabular}

had right ventricle injuries and one had injury to both ventricles. Great vessel injuries included: pulmonary artery $(n=2), \operatorname{IVC}(n=1)$, left carotid artery $(n=1)$, left subclavian artery $(\mathrm{n}=2)$, and right subclavian artery $(n=3)$ (Table 2). Forty-two percent of patients presented in stable hemodynamic condition, 33\% were in shock and $25 \%$ presented with shortness of breath (SOB). At arrival, mean heart rate was 99 beats/min (range, 0-160), mean systolic blood pressure was 100 mmHg (range, 0-154), mean oxygen saturation was $83 \%$ (range, $0-100$ ), and mean hemoglobin was 8.8 $\mathrm{mg} / \mathrm{dl}$ (range, 3-14.8) (Table 3).

Diagnosis was made mostly on clinical judgment and physical examination $(n=7)$; three patients were diagnosed on X-ray and CT scan, two on angiography and one on echocardiography. The average time lag between injury and arrival to the hospital was 2.17 hours (range, 0.5 to 4 hours), and the time lag between arrival to the hospital and incision time was 32.13 minutes (range, 10-60) (Table 3).

Intraoperative blood transfusion was also preformed, and on average, 8 packed red blood cell units (range, 0-21), 4 units fresh frozen plasma (range, 0-10) and 6 units platelets (range, $0-10$ ) were transfused.

The outcome was measured in terms of both morbidity and mortality. $53.8 \%(n=7)$ of the patients suffered from postoperative complications. Three required prolonged ventilator support, three had atelectasis, and one patient required re-exploration for bleeding. The overall mortality of patients with major thoracic vessel and cardiac trauma was found to be $15.4 \%$. Two of our patients died, three were alive with

Table 3. Time lag

\begin{tabular}{|c|c|c|c|}
\hline Injury & $\begin{array}{l}\text { Time lag between } \\
\text { injury and arrival } \\
\text { to the hospital (hours) }\end{array}$ & $\begin{array}{l}\text { Time lag between } \\
\text { arrival to the hospital and } \\
\text { incision time (minutes) }\end{array}$ & Operative procedures \\
\hline Right pulmonary artery & 1 & 20 & $\begin{array}{l}\text { Right pneumonectomy. Direct } \\
\text { closure of right pulmonary } \\
\text { artery with cardiopulmonary } \\
\text { bypass standby }\end{array}$ \\
\hline $\begin{array}{l}\text { Injury to both } \\
\text { ventricles/(VSD) }\end{array}$ & 0.5 & 50 & $\begin{array}{l}\text { Repair of both ventricles and } \\
\text { VSD under cardiopulmonary } \\
\text { bypass }\end{array}$ \\
\hline Right ventricle & 1.25 & 30 & - \\
\hline Inferior vena cava & 0.75 & 10 & - \\
\hline Left carotid artery & 4 & 22 & $\begin{array}{l}\text { Primary repair end to end after } \\
\text { mobilization. }\end{array}$ \\
\hline Left subclavian artery & 1.5 & 35 & $\begin{array}{l}\text { Gore-Tex graft interposition } \\
\text { after clavicle resection }\end{array}$ \\
\hline Right subclavian artery & 3.2 & 30 & $\begin{array}{l}\text { Gore-Tex graft interposition } \\
\text { Median sternotomy and } \\
\text { infraclavicular incision }\end{array}$ \\
\hline $\begin{array}{l}\text { Left internal mammary } \\
\text { artery (LMA) }\end{array}$ & 3 & 60 & $\begin{array}{l}\text { LMA was ligated under } \\
\text { direct vision }\end{array}$ \\
\hline Average time lag & 2.17 & 32.13 & \\
\hline
\end{tabular}


deficit and seven were alive and healthy.

\section{DISCUSSION}

By applying the protocol for cardiovascular and cardiac trauma, our trauma team was able to appropriately diagnose the trauma patients, start appropriate resuscitation, and carry out investigations and assessment. We believe that, in the past, the inevitable delay in the diagnosis led to unsuccessful thoracotomies, late transfers to the operating room and physiological deterioration of the patients. The recent increased efficiency in transporting trauma patients to hospitals has also increased the number of patients who reach the emergency room alive. ${ }^{[19-21]}$ The mortality rate of patients with aortic rupture who reach the hospital ranges from $7 \%-55 \%$. $^{[22-24]}$

Rapid diagnosis is the cornerstone in the management of these patients. In a patient with a normal chest radiograph, diagnosis of the injured aorta must be excluded. For this purpose, normal CT results can rule out an injury to the aorta and obviate the need for further examination. ${ }^{[25]}$ If the mediastinum is enlarged after trauma to the chest, angiography is required to establish a diagnosis, as both $\mathrm{CT}$ and transesophageal echocardiography can miss certain vascular injuries, especially of the arch vessels. ${ }^{[26,27]}$ In our study, $77 \%$ $(n=10)$ of patients were diagnosed on clinical judgment, physical examination, X-ray, and CT scan; 23\% required tests like angiography and echocardiography. Surgery is indicated for the repair of most arterial lesions. ${ }^{[28,29]}$

Of the patients with traumatic aortic rupture who make it to the hospital alive, $75 \%$ are hemodynamically stable. ${ }^{[30]}$ However, only $42 \%$ of the patients in our study presented in stable hemodynamic condition while $33 \%$ were in shock. In this study, the average time lag between injury and arrival to the hospital was 2.17 hours, and the time lag between arrival to the hospital and incision time was 32.13 minutes. 53.8\% of the patients suffered from postoperative complications. The overall mortality of patients with major thoracic vessel and cardiac trauma was found to be $15.4 \%$.

As the incidence of trauma is increasing worldwide, it is essential for surgeons to be prepared to handle cardiovascular and cardiac trauma injuries immediately, as delay can adversely affect the outcome in terms of both morbidity and mortality. The two most common modes of presentation of cardiac injury are cardiac tamponade and excessive hemorrhage. ${ }^{[31]}$ Equipped with knowledge of the variety of presentations, a high index of suspicion, structured approach and rapid diagnosis are the essentials for acceptable outcomes.
In conclusion, the heart and great arteries can be wounded simultaneously, and the mortality secondary to these injures is high if not treated promptly. All patients presenting with trauma to the chest should be assessed with a high index of suspicion for major cardiovascular injuries. Early diagnosis, prompt transfer to the operating room and speedy and perfect surgery influence a favorable outcome.

\section{REFERENCES}

1. Kemmerer WT, Eckert WG, Gathright JB, Reemtsma K, Creech O Jr. Patterns of thoracic injuries in fatal traffic accidents. J Trauma 1961;1:595-9.

2. Cohn SM. Pulmonary contusion: review of the clinical entity. J Trauma 1997;42:973-9.

3. Hines MH, Meredith JW. Special problems of thoracic trauma. In: Ritchie WP, Steele G, Dean RH, editors. General surgery. Philadelphia: J.B. Lippincott Co.; 1995. p. 859-72.

4. Campbell NC, Thomson SR, Muckart DJ, Meumann CM, Van Middelkoop I, Botha JB. Review of 1198 cases of penetrating cardiac trauma. Br J Surg 1997;84:1737-40.

5. Velmahos GC, Degiannis E, Souter I, Saadia R. Penetrating trauma to the heart: a relatively innocent injury. Surgery 1994;115:694-7.

6. Symbas PN. Cardiothoracic trauma. Philadelphia: WB Saunders; 1991.

7. Harman PK, Trinkle JK. Injury to the heart. In: Moore EE, Mattox KL, Feliciano DV, editors. Trauma. 2nd ed. Norwalk: Appleton \& Lange; 1991.

8. Meredith JW, Hoth JJ. Thoracic trauma: when and how to intervene. Surg Clin North Am 2007;87:95-118, vii.

9. Huerta S, Bui TD, Nguyen TH, Banimahd FN, Porral D, Dolich MO. Predictors of mortality and management of patients with traumatic inferior vena cava injuries. Am Surg 2006;72:290-6.

10. Mirvis SE. Thoracic vascular injury. Radiol Clin North Am 2006;44:181-97, vii.

11. Blatchford JW 3rd. Ludwig Rehn: the first successful cardiorrhaphy. Ann Thorac Surg 1985;39:492-5.

12. Clark GC, Schecter WP, Trunkey DD. Variables affecting outcome in blunt chest trauma: flail chest vs. pulmonary contusion. J Trauma 1988;28:298-304.

13. Parmley LF, Mattingly TW, Manion WC, Jahnke EJ Jr. Nonpenetrating traumatic injury of the aorta. Circulation 1958;17:1086-101.

14. Eddy AC, Rusch VW, Marchioro T, Ashbaugh D, Verrier ED, Dillard D. Treatment of traumatic rupture of the thoracic aorta. A 15-year experience. Arch Surg 1990;125:1351-6.

15. Bu'Lock FA, Prothero A, Shaw C, Parry A, Dodds CA, Keenan J, et al. Cardiac involvement in seatbelt-related and direct sternal trauma: a prospective study and management implications. Eur Heart J 1994;15:1621-7.

16. Prêtre R, LaHarpe R, Cheretakis A, Kürsteiner K, Khatchatourian G, Didier D, et al. Blunt injury to the ascending aorta: three patterns of presentation. Surgery 1996;119:603-10.

17. Karalis DG, Victor MF, Davis GA, McAllister MP, Covalesky VA, Ross JJ Jr, et al. The role of echocardiography in blunt chest trauma: a transthoracic and transesophageal echocardiographic study. J Trauma 1994;36:53-8.

18. Tenzer ML. The spectrum of myocardial contusion: a review. J Trauma 1985;25:620-7.

19. Shorr RM, Crittenden M, Indeck M, Hartunian SL, Rodri- 
guez A. Blunt thoracic trauma. Analysis of 515 patients. Ann Surg 1987;206:200-5.

20. Galan G, Peñalver JC, París F, Caffarena JM Jr, Blasco E, Borro JM, et al. Blunt chest injuries in 1696 patients. Eur J Cardiothorac Surg 1992;6:284-7.

21. Santavirta S, Arajärvi E. Ruptures of the heart in seatbelt wearers. J Trauma 1992;32:275-9.

22. Parmley LF, Mattingly TW, Manion WC, Jahnke EJ Jr. Nonpenetrating traumatic injury of the aorta. Circulation 1958; 17:1086-101.

23. Williams JS, Graff JA, Uku JM, Steinig JP. Aortic injury in vehicular trauma. Ann Thorac Surg 1994;57:726-30.

24. Sturm JT, Hankins DG, Young G. Thoracic aortography following blunt chest trauma. Am J Emerg Med 1990;8:92-6.

25. Cowley RA, Turney SZ, Hankins JR, Rodriguez A, Attar S, Shankar BS. Rupture of thoracic aorta caused by blunt trauma. A fifteen-year experience. J Thorac Cardiovasc Surg 1990;100:652-61.
26. Smith DC, Bansal RC. Transesophageal echocardiography in the diagnosis of traumatic rupture of the aorta. N Engl J Med 1995;333:457-8.

27. Miller FB, Richardson JD, Thomas HA, Cryer HM, Willing SJ. Role of CT in diagnosis of major arterial injury after blunt thoracic trauma. Surgery 1989;106:596-603.

28. Mattox KL. Approaches to trauma involving the major vessels of the thorax. Surg Clin North Am 1989;69:77-91.

29. Eddy AC, Rusch VW, Marchioro T, Ashbaugh D, Verrier ED, Dillard D. Treatment of traumatic rupture of the thoracic aorta. A 15-year experience. Arch Surg 1990;125:1351-6.

30. Fabian TC, Davis KA, Gavant ML, Croce MA, Melton SM, Patton JH Jr, et al. Prospective study of blunt aortic injury: helical CT is diagnostic and antihypertensive therapy reduces rupture. Ann Surg 1998;227:666-77.

31. Kulshrestha P, Das B, Iyer KS, Sampath KA, Sharma ML, Rao IM, Cardiac injuries-a clinical and autopsy profile. J Trauma 1990;30:203-7. 